\title{
Occupational stress and engagement in primary health care workers
}

\author{
Estresse ocupacional e engagement em trabalhadores da atenção primária à saúde \\ Estrés ocupacional y engagement en trabajadores de atención primaria a la salud
}

Dezolina Franciele Cardin Cordioli'

ORCID: 0000-0002-8268-122X

João Roberto Cordioli Junior'

ORCID: 0000-0002-9938-8687

Claudia Eli Gazetta'

ORCID: 0000-0002-2603-8803

Albertina Gomes da Silva'

ORCID: 0000-0002-4813-7845

Luciano Garcia Lourenção"

ORCID: 0000-0002-1240-4702

' Faculdade de Medicina de São José do Rio Preto.

São José do Rio Preto, São Paulo, Brazil.

"Universidade Federal do Rio Grande. Rio Grande,

Rio Grande do Sul, Brazil.

How to cite this article:

Cordioli DFC, Cordioli Jr JR, Gazzeta CE, Silva AG,

Lourenção LG. Occupational stress and work engagement in primary health care workers. Rev Bras Enferm. 2019;72(6):1580-7. doi: http://dx.doi.org/10.1590/0034-7167-2018-0681

Corresponding Author:

Luciano Garcia Lourenção

E-mail: luciano.famerp@gmail.com

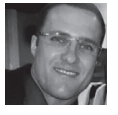

Submission: 08-29-2018

Approval: 03-09-2019

\section{ABSTRACT}

Objective: To evaluate levels of occupational stress and work engagement among primary health care workers. Method: A descriptive, correlational and transversal study was carried out in a small municipality in the countryside of São Paulo, with a nonprobabilistic sample of convenience, with 85 workers. Three self-applied instruments were used: one developed by researchers, containing sociodemographic variables; Work Stress Scale (WSS) and Utrech Work Engagement Scale (UWES). Results: Prevalence of women (72.6\%), 40 years old or more (45.9\%), 4 years and 4 months of mean working time in primary care. Thirty-one workers $(36.5 \%)$ presented significant stress (scores $\geq 2.5)$. Work engagement showed a mean of $4.1( \pm 1.2)$ to $4.4( \pm 1.4)$, classified as high in all dimensions. Occupational stress and work engagement correlated negatively. Conclusion: Workers presented high levels of work engagement; more than one-third had significant occupational stress. Workers with high levels of occupational stress tend to have lower work engagement.

Descriptors: Primary Health Care; Family Health Strategy; Health Personnel; Occupational Stress; Work Engagement.

\section{RESUMO}

Objetivo: Avaliar níveis de estresse ocupacional e engagementem trabalhadores da atenção primária à saúde. Método: Estudo descritivo, correlacional e transversal, em município de pequeno porte do interior paulista, com amostra não probabilística, de conveniência, com 85 trabalhadores. Foram utilizados três instrumentos autoaplicáveis: um elaborado pelos pesquisadores, contendo variáveis sociodemográficas; Escala de Estresse no Trabalho (EET); e Utrech Work Engagement Scale (UWES). Resultados: Prevalência do sexo feminino (72,6\%), 40 anos ou mais (45,9\%), tempo mediano de atuação na atenção primária de 4 anos e 4 meses. Trinta e um trabalhadores (36,5\%) apresentaram estresse importante (escores $\geq 2,5$ ). Engagement apresentou médias de $4,1( \pm 1,2)$ a $4,4( \pm 1,4)$, classificado como alto em todas as dimensões. Estresse ocupacional e engagement se correlacionaram negativamente. Conclusão: Os trabalhadores apresentaram altos níveis de engagement; mais de um terço apresentou estresse ocupacional importante. Trabalhadores com elevados níveis de estresse ocupacional tendem a ter engagement mais baixo.

Descritores: Atenção Primária à Saúde; Estratégia Saúde da Família; Pessoal de Saúde; Estresse Ocupacional; Engajamento no Trabalho.

\section{RESUMEN}

Objetivo: Evaluar niveles de estrés ocupacional y engagement en trabajadores de la atención primaria de salud. Método: Estudio descriptivo, correlacional y transversal, en municipio de pequeño porte del interior paulista, con muestra no probabilística, de conveniencia, con 85 trabajadores. Se utilizaron tres instrumentos auto aplicables: uno elaborado por los investigadores, conteniendo variables sociodemográficas; Escala de Estrés en el trabajo (EET) y Utrech Work Engagement Scale (UWES). Resultados: Prevalencia del sexo femenino (72,6\%), 40 años o más $(45,9 \%)$, tiempo mediano de actuación en la atención primaria de 4 años y 4 meses. Treinta y un trabajadores $(36,5 \%)$ presentaron estrés importante (puntuaciones $\geq 2,5)$. Engagement presentó promedios de $4,1( \pm 1,2)$ a $4,4( \pm 1,4)$, clasificado como alto en todas las dimensiones. El estrés ocupacional y el engagement se correlacionaron negativamente. Conclusión: Los trabajadores presentaron altos niveles de engagement; más de un tercio presentó estrés ocupacional importante. Los trabajadores con altos niveles de estrés ocupacional tienden a tener engagement más bajo.

Descriptores: Atención Primaria de Salud; Estrategia de Salud Familiar; Personal de Salud; Estrés Laboral; Compromiso Laboral. 


\section{INTRODUCTION}

The Family Health Strategy (FHS) is the model of Primary Health Care (PHC) in Brazil. It works with clients' ascription, home visit, integrality of practices, health promotion and multiprofessional team $^{(1)}$. The assignment of the professionals follow specific regulations of the Ministry of Health, as well as definitions of the scope of practices, protocols, clinical and therapeutic guidelines, as well as other technical norms established by federal, state, municipal or Federal District managers ${ }^{(2)}$.

However, in spite of the progress made with the publication of the National Occupational Health Policy (NOHP), the management of health care actions for PHC workers is still weak, besides the lack of awareness among these professionals about the importance of their occupational health ${ }^{(3-5)}$.

In the PHC services, the worker's close link with the user's territory can mean a greater vulnerability of the professional to suffering, by experiencing with greater intensity the feeling of impotence in the face of the magnitude of the health problems to be treated; to fear, by threats to the moral and physical integrity of the professional who works in open environments or in the users' own residence; and the non-recognition of efforts for the work done ${ }^{(6)}$.

In this context, professionals are liable to occupational stress, due to physical, psychological and social risks at work ${ }^{(7)}$. Stress is conceptualized from the interactionist model that considers the relationship between the environment and the person or group as responsible for the attrition. It is defined as any stimulus emanating from the external or internal environment that exceeds the adaptation sources of an individual or social system ${ }^{(8)}$.

Among the factors triggering the process of mental illness among PHC workers, the most important are those associated with work, such as overload, precarious employment and working conditions, pressure for meeting goals and results, and lack of autonomy ${ }^{(9)}$.

On the other hand, engagement makes the professional linked to his work, with high feelings of inspiration, well-being and authentic pleasure for what he performs professionally. It comprises a mental state, dispositional and positive of intense pleasure and deep connection with labor action, being an indicator of workers' health $^{(10)}$, composed of three dimensions: vigor, dedication and absorption ${ }^{(11-12)}$.

Vigor is a behavioral-energy component, characterized by high levels of energy and mental endurance at work, willingness to invest with effort and persistence, even in the face of difficulties; the dedication, related to an element of emotional charisma, characterized by a strong involvement in the work and experimentation of a sense of meaning, enthusiasm, inspiration, pride and challenge; and absorption related to a cognitive component, characterized by full concentration at work, task-focused attention, mental clarity, and enjoyment in the performance of their work $^{(11-12)}$, as well as a general score that measures the positive mental state of the worker.

Engagement is an always positive and intense state, more strongly related to the way professionals perform their work than to organizational goals, work tasks or the types of organization in which they are inserted ${ }^{(13)}$. However, it comprises a dynamic process that, although stable over time, can be altered by working conditions and, when this is detected in a negative way, it is observed that several aspects that harm the workers' health are in evidence ${ }^{(13)}$.

In the case of $\mathrm{PHC}$, for the development of engagement among the team, it is recommended to implement activities considered significant for professionals, which will result in positive working relationships, better job performance and greater job satisfaction $^{(14)}$. Therefore, the engagement focus benefits the professionals, offering a competitive advantage to the organizations where they are inserted ${ }^{(15)}$.

Besides the personal resources that support engagement, such as self-efficacy, self-esteem, beliefs and coping strategies, the construct also has relation with specific characteristics of the workplace, such as quality and quantity of available resources, teamwork, autonomy at work, content of work activity, relationship with managers, feedback, performance evaluation, coaching and training ${ }^{(15-16)}$. Other authors also argue that factors such as social support, job performance, positive psychological capital, optimism, organizational needs, customer satisfaction and resilience are associated with engagement ${ }^{(11,17)}$.

Given the above, the relevance of studying engagement levels, as well as the presence of occupational stress and more present stressors, in the perception of PHC workers as a way of improvement, is justified because of the strengthening of positive aspects of the worker's relationship with the work environment, favoring the prevention of aggravations to the physical and psychological health of these professionals, and directing of restructuring strategies that improve working conditions, with repercussion in increasing productivity and quality of care.

\section{OBJECTIVE}

To evaluate the levels of occupational stress and engagement among primary health care workers in a small municipality in the countryside of São Paulo.

\section{METHOD}

\section{Ethical aspects}

Before the data collection, the study was approved by the Committee of Ethics in Research in Human Beings of the Faculty of Medicine of São José do Rio Preto, with Opinion No. 1.890.199, dated 01.11.2017 (CAAE: 63455516.3.0000.5415). The ethical precepts of voluntary and consensual participation of each study subject were respected.

\section{Design, location of the study and study period}

A quantitative, descriptive, correlational and cross-sectional study was carried out in the municipality of Adamantina, São Paulo, in 2017, with a non-probabilistic convenience sample, which included 85 workers from the PHC units.

\section{Population or sample; inclusion and exclusion criteria}

The study population consisted of all workers ( 21 physicians, 24 nurses, 30 nursing assistants/technicians, 44 community 
health agents (CHA), 11 dentists and 20 vector control agents) of the city's seven PHC units. Professionals on vacation during the period of data collection and/or removed from professional activities for any other reason were excluded.

The study sample was defined by convenience and was composed by the professionals who participated in the study, responding to the instruments.

\section{Study protocol}

The data collection was performed with three self-applied instruments. It was elaborated by the researchers, containing closed questions about training, age group, gender, marital status, income, schooling, if you are satisfied and/or if you have already thought about giving up the profession/function.

The Work Stress Scale (WSS), validated by Tamayo and Paschoal $^{(18)}$, composed of 23 negative affirmations, with a scale of 5 points, ranging from " 1 - totally disagree" to " 5 - totally agree", being that, the higher the score, the greater the stress. The WSS is a general measure of stress, whose items address several stressors and emotional reactions constantly associated with them ${ }^{(18)}$.

The Brazilian version of the Utrech Work Engagement Scale (UWES), validated by Vazques et al. ${ }^{(19)}$, was composed of 17 three-dimensional self-assessment items (Vigor, Dedication and Absorption) and a general Score ${ }^{(20-21)}$. Vigor refers to high levels of energy and resilience, the willingness to invest efforts, not to become easily fatigued, and persist in the face of difficulties. Dedication refers to a sense of meaning for work, feeling enthusiastic and proud about the work, feeling inspired and challenged by it. Absorption refers to being totally immersed in the work and having difficulty letting go of it, time goes by quickly and forgetting everything around ${ }^{(19-20)}$.

The data collection was scheduled with the nurses of the health units and performed during the team meeting. After the researchers explained study objectives, the signatures of the Informed Consent Term were collected from the workers who agreed to participate in the study, and soon after, the questionnaires were delivered to all professionals who answered and deposited them in an brown envelope, without identification, to preserve the identity of the respondents.

\section{Analysis of results and statistics}

Sociodemographic data were used to characterize the study population. Occupational stress was evaluated based on the calculation of a mean score obtained by the workers and among the professional categories, for all items of the scale and for each item of the scale, identifying the most present stressors according to the workers' perception. Significant levels of stress are considered as mean values equal to or greater than 2.5.

The calculations of the scores of engagement dimensions were performed according to the statistical model proposed in the Utrecht Work Engagement Scale (UWES) ${ }^{(20)}$, presenting mean and standard deviation for each UWES dimension. The interpretation of the values obtained was then performed, from the decoding of the Preliminary Manual UWES, being: 0 to $0.99=$ Very low; 1 to $1.99=$ Low $; 2$ to $3.99=$ Medium; 4 to $4.99=$ High; 5 to $6=$ Very high.
The comparison of the sociodemographic characteristics of the professionals distribution was performed by the chi-square test and, for the mean scores comparisons of the UWES dimensions, the F-test was used in the analysis of variance (ANOVA), considering a level of significance of $95 \%(p<0,05)$.

Finally, the correlation analysis between the occupational stress and the dimensions of the UWES (Dedication, Absorption, Vigor and General Score) was performed using the Pearson correlation test, with significance level of $5 \%(p<0.05)$. The correlation between the variables was considered weak for $r$ values up to 0.30 , moderate for values between 0.40 and 0.60 , and strong for values greater than 0.70 .

\section{RESULTS}

A total of 85 workers, including physicians (10.6\%), nurses (17.6\%), dentists (5.9\%), nursing assistants/technicians (14.1\%) and community health agents (34.1\%) and vector control agents (17.6\%). There was no participation of oral health auxiliary/technicians because there was no position in the municipality. There was a prevalence of female workers (71.8\%), with 40 years old or older (45.9\%). The age of the workers ranged from 22 to 59 years old, with a median of 39 years old ( mean $=41.5 ; \pm 9.9$ years old). The work time of the workers in the $\mathrm{PHC}$ ranged from 4 months to 33 years, with a median of 4 years and 4 months.

Regarding occupational stress, the sample mean was 2.3 $(\mathrm{sd}= \pm 0.8$; minimum $=1.0$ and maximum $=4.4)$. The general evaluation of study participants showed that 31 (36.5\%) workers presented scores compatible with significant stress $(\geq 2.5)$. There were considerable levels of stress among vector control agents $(2.9 ; \pm 1.0)$, professionals with incomplete higher education (2.6; \pm 0.8 ), family income up to a minimum wage $(2.5 ; \pm 0.8)$, up to two years of professional performance in the PHC $(2.5 ; \pm 0.8)$, who were unsatisfied with the profession/occupation $(3.0 ; \pm 0.8)$ and who already thought about giving up of the profession/ occupation $(2.6 ; \pm 0.8)$.

Table 1 - Evaluation of occupational stress, according to the sociodemographic variables of Primary Health Care Workers, São José do Rio Preto, São Paulo, Brazil, 2017-2018

\begin{tabular}{lc}
\hline \multicolumn{1}{c}{ Variables } & Mean $( \pm \mathbf{s d}) \boldsymbol{p}$ value \\
\hline Professional Category & \\
Physician & $1.5( \pm 0.4)$ \\
Dentist & $2.4( \pm 0.6)$ \\
Nurse & $1.9( \pm 0.7) \quad 0.001$ \\
Auxiliary/Nursing Technician & $2.1( \pm 0.7) \quad 2.4( \pm 0.5)$ \\
Community Health Agent & $2.9( \pm 1.0)$ \\
Vector control agent & \\
Age Group & $2.3( \pm 0.4)$ \\
From 18 to 28 years old & $2.3( \pm 0.7) \quad 0.917$ \\
From 29 to 39 years old & $2.3( \pm 0.9)$ \\
40 years old or more & \\
Level of education & $2.3( \pm 0.7)$ \\
High school & $2.6( \pm 0.8)$ \\
Incomplete Higher Education & $2.4( \pm 0.9) \quad 0.311$ \\
Complete higher education & $2.1( \pm 0.7)$ \\
Graduation (Specialization) & $1.9(* *)$ \\
Master's Degree & \multicolumn{2}{c}{ To be continued }
\end{tabular}


Table 1 (concluded)

\begin{tabular}{|c|c|c|}
\hline Variables & Mean ( \pm sd) & $p$ value \\
\hline \multicolumn{3}{|l|}{ Marital Status } \\
\hline $\begin{array}{l}\text { Married } \\
\text { Single } \\
\text { Divorced } \\
\text { Widowed }\end{array}$ & $\begin{array}{l}2.3( \pm 0.8) \\
2.4( \pm 0.7) \\
2.1( \pm 1.1) \\
2.4( \pm 0.6)\end{array}$ & 0.879 \\
\hline \multicolumn{3}{|l|}{ Family Income* } \\
\hline $\begin{array}{l}\text { Up to } 1 \text { Minimum Wage } \\
\text { From } 2 \text { to } 5 \text { Minimum Wages } \\
\text { From } 6 \text { to } 10 \text { Minimum Wages } \\
\text { More than } 10 \text { minimum wages }\end{array}$ & $\begin{array}{l}2.5( \pm 0.8) \\
2.3( \pm 0.86) \\
2.0( \pm 0.3) \\
2.3( \pm 1.0)\end{array}$ & 0.506 \\
\hline \multicolumn{3}{|l|}{ Time of experience PHC } \\
\hline $\begin{array}{l}\text { Up to } 2 \text { years } \\
\text { From } 3 \text { to } 10 \text { years } \\
\text { Above } 10 \text { years }\end{array}$ & $\begin{array}{l}2.5( \pm 0.8) \\
2.3( \pm 0.8) \\
2.2( \pm 0.8)\end{array}$ & 0.363 \\
\hline \multicolumn{3}{|l|}{ Satisfied with the Profession/Occupation } \\
\hline $\begin{array}{l}\text { Yes } \\
\text { No }\end{array}$ & $\begin{array}{l}2.2( \pm 0.7) \\
3.0( \pm 0.8)\end{array}$ & $<0.001$ \\
\hline \multicolumn{3}{|c|}{ Thought about giving up the Profession/Occupation } \\
\hline $\begin{array}{l}\text { Yes } \\
\text { No }\end{array}$ & $\begin{array}{l}2.6( \pm 0.8) \\
2.2( \pm 0.7)\end{array}$ & 0.024 \\
\hline
\end{tabular}

Note: PHC - Primary Health Care; *Minimum Wage Value: $R \$ 937.00 ; * *$ Variable with only one worker; standard deviation absent.
The most present stressors according to the workers' perception studied were: [Q13] deficiency in professional training (3.0; \pm 1.5$)$; [Q5] deficiency in the disclosure of information about organizational decisions (2.9; \pm 1.2$)$; [Q16] lack of perspective for career growth $(2.9 ; \pm 1.5) ;[Q 12]$ presence of discrimination/favoritism in the work environment (2.7; \pm 1.4$)$; [Q15] low valuation by the superiors (2.7; $\pm 1.4)$; [Q1] form of task distribution $(2.7 ; \pm 1.3)$; [Q2] type of control $(2.6 ; \pm 1.1)$; [Q19] lack of understanding of responsibilities $(2.5 ; \pm 1.5)$; [Q22] insufficient time to perform work $(2.5 ; \pm 1.3)$.

In the reliability analysis, Cronbach's alpha coefficient values ranged from 0.754 to 0.924 , indicating reliability of the results. The average engagement size ranged from $4.1( \pm 1.2)$ to $4.4( \pm 1.4)$, classified as high.

In the analysis of the engagement, based on the sociodemographic characteristics of the workers, it was observed that the vector control agents presented mean scores for all dimensions of the UWES [Dedication: 3.3 ( \pm 1.3$)$; Absorption: 3.4 ( \pm 1.3$)$; Vigor: 3.7 ( \pm 1.4$)$; Overall score: $3.5( \pm 1.4)$ ], showing that the ratio of these workers to the work environment is less positive than the others. Mean scores were also found in all UWES dimensions for professionals aged 18 to 28 years [Dedication: 3.9 ( \pm 1.5$)$; Absorption: 3.4 ( \pm 1.0$)$;

Table 2 - Assessment of the engagement, according to Primary Care Workers, São José do Rio Preto, São Paulo, Brazil, 2017-2018

\begin{tabular}{cccccccc}
\hline UWES Dimensions & Cronbach's Alpha & Min & Max & Md & Mean \pm sd & Cl (95\%) & Interpretation \\
\hline Vigor & 0.808 & 0.4 & 6.0 & 4.0 & $4.4 \pm 1.4$ & $4.0-4.5$ & High \\
Dedication & 0.857 & 0.8 & 6.0 & 4.6 & $4.1 \pm 1.2$ & $4.1-4.7$ & High \\
Absorption & 0.754 & 1.0 & 6.0 & 4.2 & $4.3 \pm 1.1$ & $3.8-4.3$ & High \\
Overall Score & 0.924 & 0.8 & 6.0 & 4.2 & $4.3 \pm 1.1$ & $4.0-4.5$ & High \\
\hline
\end{tabular}

Note: Min: minimum; Max: maximum; Md: median; sd: standard deviation; 95\% Cl: 95\% confidence interval; UWES: Utrecht Work Engagement Scale.

Table 3 - Levels of engagement, according to sociodemographic characteristics of primary health care workers. São José do Rio Preto, São Paulo, Brazil, 2017-2018

\begin{tabular}{|c|c|c|c|c|c|}
\hline Variables & & $\begin{array}{l}\text { Dedication } \\
\text { Mean ( } \pm s d)\end{array}$ & $\begin{array}{l}\text { Absorption } \\
\text { Mean ( } \pm \text { sd) }\end{array}$ & $\begin{array}{c}\text { Vigor } \\
\text { Mean }( \pm s d)\end{array}$ & $\begin{array}{c}\text { Overall score } \\
\text { Mean ( } \pm \text { sd) }\end{array}$ \\
\hline \multicolumn{6}{|l|}{ Professional Category } \\
\hline Physician & & $5.4( \pm 0.5)^{c}$ & $4.5( \pm 0.7)^{b}$ & $4.5( \pm 0.9)^{b}$ & $4.8( \pm 0.6)^{b}$ \\
\hline Dentist & & $4.6( \pm 1.1)^{b}$ & $4.4( \pm 1.2)^{b}$ & $4.8( \pm 0.9)^{b}$ & $4.6( \pm 1.1)^{b}$ \\
\hline Nurse & & $5.1( \pm 0.9)^{c}$ & $4.8( \pm 1.1)^{b}$ & $4.7( \pm 1.2)^{b}$ & $4.8( \pm 1.0)^{b}$ \\
\hline Auxiliary/Nursing Technician & & $4.7( \pm 1.2)^{b}$ & $4.2( \pm 1.4)^{b}$ & $4.6( \pm 1.2)^{b}$ & $4.5( \pm 1.2)^{b}$ \\
\hline Community Health Agent & & $4.1( \pm 1.2)^{b}$ & $3.8( \pm 1.0)^{a}$ & $4.1( \pm 0.9)^{b}$ & $4.0( \pm 0.9)^{b}$ \\
\hline Vector control agent & & $3.3( \pm 1.3)^{a}$ & $3.4( \pm 1.3)^{a}$ & $3.7( \pm 1.4)^{\mathrm{a}}$ & $3.5( \pm 1.4)^{\mathrm{a}}$ \\
\hline & $p$ value & 0.001 & 0.025 & 0.102 & 0.008 \\
\hline \multicolumn{6}{|l|}{ Age Group } \\
\hline From 18 to 28 years old & & $3.9( \pm 1.5)^{a}$ & $3.4( \pm 1.0)^{\mathrm{a}}$ & $3.9( \pm 1.1)^{\mathrm{a}}$ & $3.7( \pm 1.2)^{\mathrm{a}}$ \\
\hline From 29 to 39 years old & & $4.3( \pm 1.5)^{b}$ & $4.0( \pm 1.3)^{b}$ & $4.2( \pm 1.1)^{b}$ & $4.2( \pm 1.2)^{b}$ \\
\hline 40 years old or more & & $4.5( \pm 1.3)^{b}$ & $4.2( \pm 1.1)^{b}$ & $4.3( \pm 1.2)^{b}$ & $4.3( \pm 1.1)^{b}$ \\
\hline & $p$ value & 0.541 & 0.291 & 0.736 & 0.468 \\
\hline \multicolumn{6}{|l|}{ Level of education } \\
\hline High school & & $4.5( \pm 1.2)^{b}$ & $4.1( \pm 1.2)^{b}$ & $4.5( \pm 1.1)^{b}$ & $4.4( \pm 1.0)^{b}$ \\
\hline Incomplete Higher Education & & $4.2( \pm 1.2)^{\mathrm{b}}$ & $3.9( \pm 0.8)^{\text {a }}$ & $4.0( \pm 0.8)^{b}$ & $4.0( \pm 0.8)^{b}$ \\
\hline Complete higher education & & $3.7( \pm 2.0)^{a}$ & $3.6( \pm 1.5)^{a}$ & $4.0( \pm 1.4)^{b}$ & $3.8( \pm 1.5)^{\mathrm{a}}$ \\
\hline Graduation (Specialization) & & $5.1( \pm 0.8)^{c}$ & $4.8( \pm 0.9)^{b}$ & $4.6( \pm 1.1)^{b}$ & $4.8( \pm 0.9)^{b}$ \\
\hline Master's Degree & & $3.0(* *)^{a}$ & $2.3(* *)^{a}$ & $3.3(* *)^{a}$ & $2.9\left(^{* *}\right)^{a}$ \\
\hline & $p$ value & 0.024 & 0.009 & 0.206 & 0.029 \\
\hline \multicolumn{6}{|l|}{ Marital Status } \\
\hline Married & & $4.6( \pm 1.2)^{b}$ & $4.3( \pm 1.2)^{b}$ & $4.6( \pm 1.1)^{b}$ & $4.5( \pm 1.1)^{b}$ \\
\hline Single & & $3.8( \pm 1.5)^{a}$ & $3.6( \pm 1.2)^{a}$ & $3.8( \pm 1.0)^{\mathrm{a}}$ & $3.7( \pm 1.1)^{\mathrm{a}}$ \\
\hline Divorced & & $5.7( \pm 0.3)^{c}$ & $4.6( \pm 0.6)^{b}$ & $4.2( \pm 0.8)^{b}$ & $4.8( \pm 0.2)^{b}$ \\
\hline \multirow[t]{2}{*}{ Widowed } & & $4.5( \pm 1.6)^{b}$ & $4.4( \pm 1.1)^{\mathrm{b}}$ & $3.6( \pm 2.0)$ & $4.2( \pm 1.5)^{b}$ \\
\hline & $p$ value & 0.031 & 0.054 & 0.045 & 0.036 \\
\hline
\end{tabular}




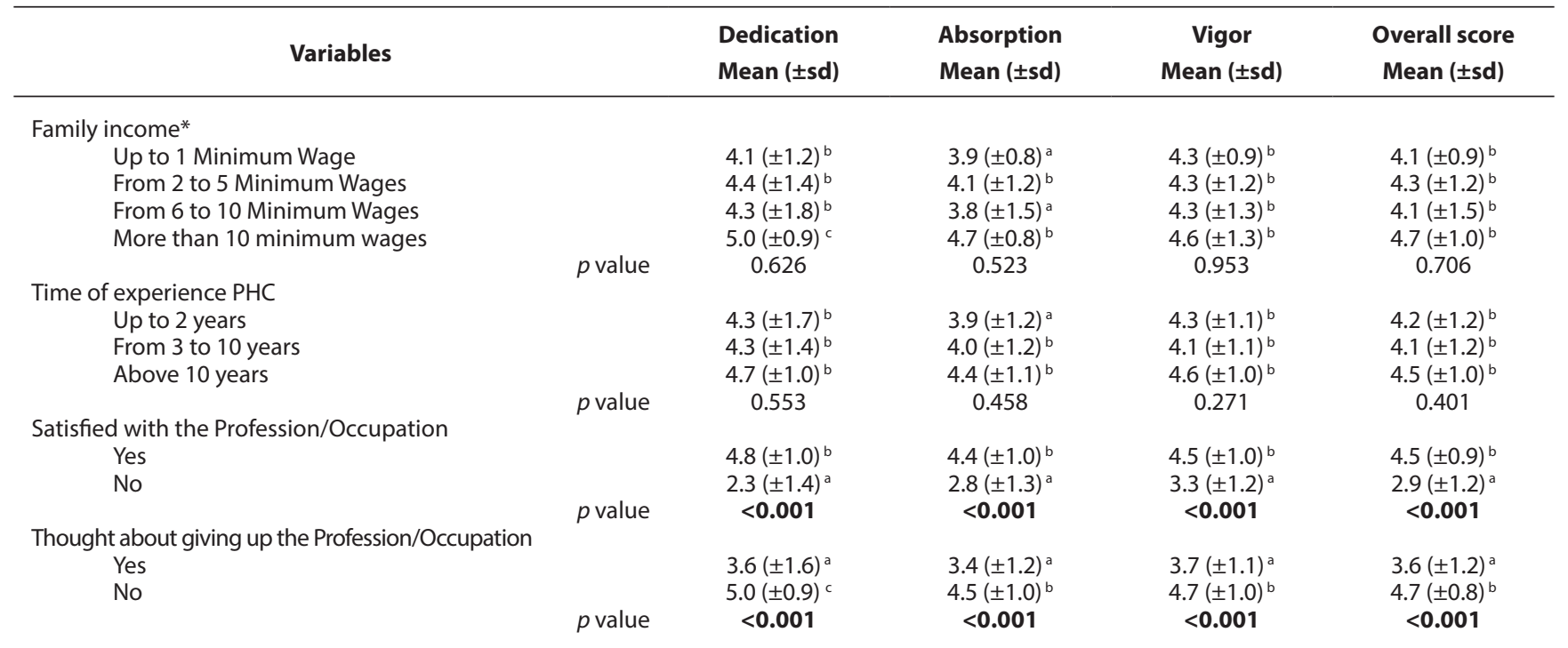

Note: PHC - Primary Health Care; *Minimum Wage Value: $R \$ 937.00 ;{ }^{* *}$ Variable with only one worker; standard deviation absent. ${ }^{a}$ Mean score; ${ }^{b: H i g h ~ s c o r e ; ~}{ }^{c i}$ Very high score.

Table 4-Correlations between the Work Stress Scale (WSS) and Utrecht Work Engagement (UWES), São José do Rio Preto, São Paulo, Brazil, 2017-2018

\begin{tabular}{lcc}
\hline & EET & $\boldsymbol{p}$ value \\
\hline Dedication & $-0.416^{* * *}$ & $<\mathbf{0 . 0 0 1}$ \\
Absorption & $-0.292^{* *}$ & 0.008 \\
Vigor & $-0.224^{*}$ & 0.042 \\
Overall score & $-0.333^{* *}$ & 0.002 \\
\hline
\end{tabular}

Note: WSS: Work Stress Scale; *: $p<0.05 ;{ }^{* *}: p<0.01$.

Vigor: $3.9( \pm 1.1)$; Overall score: $3.7( \pm 1.2)$, unmarried [Dedication: 3.8 ( \pm 1.5$)$; Absorption: 3.6 ( \pm 1.2$)$; Vigor: 3.8 ( \pm 1.0$)$; Overall score: $3.7( \pm 1.1)$ ], who reported being unsatisfied with the profession/ occupation[Dedication: 2.3 ( \pm 1.4$)$; Absorption: 2.8 ( \pm 1.3$)$; Vigor: 3.3 ( \pm 1.2$)$; Overall score: $2.9( \pm 1.2)$ ] and who have already thought about giving up the profession/occupation [Dedication: $4.8( \pm 1.0)$; Absorption: 4.4 ( \pm 1.0$)$; Vigor: 4.5 ( \pm 1.0$)$; Overall score: $4.5( \pm 0.9)$ ].

Occupational stress and engagement correlate negatively. There was a weak correlation between occupational stress with Absorption ( $\mathrm{r}$ : $-0.292, p=0.008)$ and Vigor ( $r:-0.224, p=0.042)$, and moderate with Dedication ( $r:-0.416, p<0.001)$, and general Score $(r:-0.333, p=0.002)$.

\section{DISCUSSION}

The profile of the workers in this study - women with 40 years old and over, duration of work in the PHC from 3 to 10 years corroborates the profile of PHC workers in Brazilian municipalities $^{(21-23)}$. We highlight the prevalence of female professionals, as a result of the process of feminization of health professions, in Brazil and in other countries ${ }^{(24-25)}$.

The percentage of workers with significant levels of stress found in this study is consistent with other studies, which indicate high levels of stress among PHC workers, confirming that workers are affected by problems or damages to their physical and mental health ${ }^{(21,26-30)}$.

The variation of stress levels, according to the sociodemographic variables of the workers, observed in this study, corroborates the literature that states that, although there are variations, psychic suffering affects all professional categories ${ }^{(30)}$ and its perception is related to individual, professional and work environment aspects, especially: gender, marital status, professional category, team composition and time spent in the same team ${ }^{(28)}$.

This study identified important stressors, such as deficits in professional training and dissemination of information on organizational decisions, lack of perspective for professional growth, discrimination/favoritism in the work environment, low valorization by superiors, distribution of tasks, lack of understanding of responsibilities and insufficient time to perform the work, allowing a general measure of stress ${ }^{(18)}$.

A study with professionals from Santa Maria, Rio Grande do Sul, found situations that $\mathrm{CHA}$, because they reside in the same community where they work, are more exposed to physical risks for working directly in the households of the community in which they live and, because of the link with the families enrolled, people expect more from them, showing thus a greater tendency to psychological exhaustion ${ }^{(21)}$. According to the authors, the main causes of stress of the professionals are: lack of material resources, labor conflicts, lack of professional preparation, external pressure, party politics, lack of professional recognition, irresponsibility, power struggle, competition, authoritarianism, work overload, involvement of personal life in the work, financial problems and education of the children, accomplishment of the team work, interpersonal relationship with the headship, corroborating the results of this study.

Likewise, the CHA of the municipality of Taquari, also in Rio Grande do Sul, reported that the inadequate conditions for carrying out the work, such as a lack of material resources and ergonomically inadequate equipment, cause physical exhaustion, as well as the feeling of insecurity experienced during home visits, proximity to the residents and emotional involvement, which cause a psychic load that leads to professional exhaustion ${ }^{(31)}$.

In the case of the municipality studied, these conditions also apply to vector control agents, which perform a similar function to $\mathrm{CHA}$ and, therefore, work under the same conditions as the $\mathrm{CHA}$.

These results contribute to the orientation of promoting actions and protection of workers' health, such as reorganization of 
the work process, listening and stress management techniques, and moments of reflection and support for workers ${ }^{(26,29)}$, seeking to reduce suffering and damages that may compromise their health and ensure compliance with the guidelines of the new National Basic Care Policy (PNAB), especially the longitudinality of care - guaranteeing the "continuity of the care relationship, building bond and accountability between professionals and users over time, in a permanent and consistent way" (page 70$)^{(2)}$.

The levels of engagement found in PHC workers in this study are superior to those reported in studies with Brazilian health professionals ${ }^{(30,32-33)}$ and similar to those found in studies with Irish ${ }^{(34)}$ and Saudi ${ }^{(35)}$ nurses, showing that PHC workers have a strong positive relation with their job (General score), are involved and enthusiastic (Dedication), concentrated (Absorption) and with high levels of energy and resilience (Vigor). These results are positive and show the potential of professionals to fulfill their duties, as established by the PNAB ${ }^{(2)}$.

According to the literature, engagement is a phenomenon that is related to the group that the worker belongs to and is influenced by individual, organizational and work-specific characteristics ${ }^{(36-37)}$. This study evidences these affirmations when it finds differences between the levels of engagement according to sociodemographic and professional characteristics, such as the lower scores between the control agents of endemics, younger and single professionals.

Finally, it was observed that occupational stress correlates negatively with engagement, being an important factor for the commitment of work activities in PHC, and can directly compromise the care quality provided to users of the health system. As engagement is directly related to work performance, stimulating individual and collective engagement can reduce occupational stress and increase the involvement of professionals in the work, providing well-being of the teams, improving the quality of the service provided to the users and increasing the resoluteness. However, this is not an easy task, since the work environment is surrounded by positive and negative forces, which influence the engagement levels of professionals ${ }^{(37)}$.

As already discussed, there are a number of factors that compromise the physical and mental health of PHC workers, interfering with work performance. In this context, it is essential that managers and employees of the PHC services know in depth their attributions, defined by the new $\mathrm{PNAB}^{(2)}$, discuss and identify the factors that cause physical and psychological exhaustion, which may compromise professional performance, quality and of health services. This diagnosis will allow the planning of interventions, as well as the implementation of public policies that ensure adequate staffing and a work environment that promotes the health and well-being of workers.

\section{Study limitations}

The main limitation of the study was the performance in a single municipality, limiting the analysis of the results. Thus, it is suggested to carry out other studies, with a greater number of workers and inclusion of municipalities from different regions, allowing to compare and discuss differences and similarities, contributing to the knowledge about occupational stress and engagement among PHC workers.

\section{Contributions to the field of nursing and public health}

The study contributes to the reflection on the importance of a healthy working environment for $\mathrm{PHC}$ workers, including nursing workers. The identification of stressors and levels of engagement are useful indicators for the reflection on the structuring of the teams and the planning of the work process, from which the new PNAB is established; they also contribute to the direction of the health care policies of the workers, in order to create an environment conducive to the labor practice of all the workers involved in the assistance to the population, guaranteeing the provision of services with safety and quality.

\section{CONCLUSION}

The profile of PHC workers studied is predominantly of women, with 40 years old or older, with a duration of 3 to 10 years in PHC. More than a third of the workers presented scores compatible with important occupational stress.

The major stressors of the workers were: lack of professional training and dissemination of information about organizational decisions, lack of perspective for professional growth, discrimination/favoritism in the work environment, low valorization by superiors, distribution of tasks, lack of understanding of responsibilities and insufficient time to do the job. Workers with higher levels of stress were: vector control agents, workers with incomplete higher education, family income up to a minimum wage, up to two years of professional work in the $\mathrm{PHC}$, who were unsatisfied with the profession/occupation and who already thought about giving up their profession.

In a general analysis, the workers presented high levels of engagement, surpassing the indices presented by other groups of Brazilian professionals. However, some groups had lower indexes, such as vector control agents, younger and single workers, showing a compromise of the relationship between these workers and the work environment.

Occupational stress and engagement correlate negatively, so workers with high levels of occupational stress tend to have lower engagement.

\section{REFERENCES}

1. Gomes KO, Cotta RMM, Araújo RMA, Cherchiglia ML, Martins TCP. Atenção Primária à Saúde - a "menina dos olhos" do SUS: sobre as representações sociais dos protagonistas do Sistema Único de Saúde. Cienc Saude Coletiva. 2011;16(Supl 1):881-92. doi: 10.1590/ S1413-81232011000700020

2. Ministério da Saúde (BR). Portaria n².436, de 21 de setembro de 2017. Aprova a Política Nacional de Atenção Básica, estabelecendo a revisão de diretrizes para a organização da Atenção Básica, no âmbito do Sistema Único de Saúde (SUS) [Internet]. Brasília; 2017 [cited 2018 
Jun 12]. Available from: http://bvsms.saude.gov.br/bvs/saudelegis/gm/2017/prt2436_22_09_2017.html

3. Pereira ESSL, Silva ACC. Impactos das mudanças no processo de trabalho dos profissionais de saúde: o que diz a literatura. Rev Enferm Contemp. 2013;2(1):209-24. doi: 10.17267/2317-3378rec.v2i2.171

4. Souza TS, Virgens LS. Saúde do trabalhador na Atenção Básica: interfaces e desafios. Rev Bras Saude Ocup. 2013;38(128):292-301. doi: 10.1590/S0303-76572013000200016

5. Silva VS, Prazeres TA, Lima MAG. Configurações do trabalho domiciliar no território da Estratégia de Saúde da Família [Internet]. Rev Enferm Contemp. 2017[cited 2018 Jun 12];6(Supl-1):77. Available from: https://www5.bahiana.edu.br/index.php/enfermagem/issue/ viewlssue/103/13

6. Lancman S, Ghirardi MIG, Castro ED, Tuacek TA. Repercussions of violence on the mental health of workers of the Family Health Program. Rev Saude Publica. 2009;43(4). 10.1590/S0034-89102009005000036

7. Justo CF. Reducción de los niveles de estrés y ansiedad em médicos de Atención Primaria mediante la aplicación de um programa de entrenamiento em conciencia plena (mindfulness). Aten Primaria. 2010;42(11):564-70. doi: 10.1016/j.aprim.2009.10.020

8. Lazarus RS, Folkman S. Stress, appraisal, and coping. New York: Springer; 1984.

9. Carreiro GSP, Ferreira Filha MO, Lazarte R, Silva AO, Dias MD. O processo de adoecimento mental do trabalhador da Estratégia Saúde da Família. Rev Eletr Enf. 2013;15(1):146-55. doi: 10.5216/ree.v15i1.14084

10. Schaufeli WB. What is engagement? In: Truss C, Alfes K, Delbridge R, Shantz A, Soane E, editors. Employee Engagement in Theory and Practice. London: Routledge; 2013. p. 15-35.

11. Salanova M, Schaufeli WB. El Engagement en el trabajo: cuando el trabajo se convierte en pasión. Madrid: Alianza Editorial; 2009.

12. Araújo I, Esteves R. Engagement em docentes do ensino superior: uma abordagem exploratória. Enferm Univ. 2016;13(2):73-9. doi: 10.1016/j.reu.2016.03.006

13. Magnan ES, Vazquez ACS, Pacico JC, Hutz CS. Normatização da versão Brasileira da Escala Utrecht de Engajamento no Trabalho. Aval Psicol. 2016;15(2):133-40. doi: 10.15689/ap.2016.1502.01

14. Merino CF, Gallardo RY. Describiendo el engagement en profesionales de enfermería de atención primaria de salud. Cienc Enferm. 2014:20(3):131-40. doi: 10.4067/S0717-95532014000300012

15. Porto-Martins PC, Basso-Machado PG, Benevides-Pereira AMT. Engagement no trabalho: uma discussão teórica. Fractal Rev Psicol. 2013;25(3):629-44. doi: 10.1590/S1984-02922013000300013

16. Lisbona A, Morales JF, Palací FJ. El engagement como resultado de la socialización organizacional. Int J Psychol Psychol Ther [Internet]. 2009 [cited 2018 Feb 12];9(1):89-100. Disponible en: https://www.ijpsy.com/volumen9/num1/223/el-engagement-como-resultado-de-lasocializaci-ES.pdf

17. Bakker AB, Leiter MP. Where to go from here: integration and future research on work engagement. In.: Bakker AB, Leiter MP, editors. Work engagement: a handbook of essential theory and research. New York: Psychology Press, 2010. p. 181-196.

18. Paschoal T, Tamayo A. Validação da escala de estresse no trabalho. Estud Psicol. 2004;9(1):45-52. doi: 10.1590/S1413-294X2004000100006

19. Vazquez ACS, Magnan ES, Pacico JC, Hutz CS, Schaufeli WB. Adaptation and validation of the Brazilian version of the Utrecht Work Engagement Scale. Psico-USF. 2015;20(2):207-17. doi: 10.1590/1413-82712015200202

20. Schaufeli W, Bakker A. Utrecht Work Engagement Scale [Internet]. Curitiba: GEPEB; 2009 [cited 2018 Jun 12]. Available from: https://www. wilmarschaufeli.nl/publications/Schaufeli/Test\%20Manuals/Test_manual_UWES_Brazil.pdf

21. Medeiros PA, Silva LC, Amarante IM, Cardoso VG, Mensch KM, Naman M, et al. Condições de saúde entre profissionais da atenção básica em saúde do município de Santa Maria-RS. Rev Bras Cien Saude [Internet]. 2016 [cited 2018 jan. 24];20(2):115-22. Available from: http://www. periodicos.ufpb.br/ojs2/index.php/rbcs/article/view/18961

22. Maissiat GS, Lautert L, Pai DD, Tavares JP. Work context, job satisfaction and suffering in primary health care. Rev Gaucha Enferm. 2015;36(2):42-9. doi: 10.1590/1983-1447.2015.02.51128

23. David HMSL. The role of the community health worker to strengthen popular education in health. J Rev Fundam Care Online. 2017;9(2):3718. doi: doi: 10.9789/2175-5361.2017.v9i2.371-378

24. Matos IB, Toassi RFC, Oliveira MC. Profissões e ocupações de saúde e o processo de feminização: tendências e implicações. Athenea Digital [Internet]. 2013 [cited 2018 Jan 24];13(2):239-44. Available from: https://www.lume.ufrgs.br/bitstream/handle/10183/118035/000894801.pdf

25. Wermelinger M, Machado MH, Tavares MFL, Oliveira ES, Moysés NMN. A força de trabalho do setor de saúde no Brasil: focalizando a feminização. Rev Divulg Saude Debate [Internet]. 2010 [cited 2018 Jan 24];45(1):54-70. Available from: http://www.ensp.fiocruz.br/ observarh/arquivos/A\%20Forca\%20de\%20Trabalho\%20do\%20Setor\%20de\%20Saude\%20no\%20Brasil\%20.pdf

26. Santos SCR, Viegas AIF, Morgado CIMO, Ramos CSV, Soares CND, Roxo HMCJ, et al. Prevalência de burnout em médicos residentes de Medicina Geral e Familiar em Portugal. Rev Bras Med Fam Comunidade. 2017;12(39):1-9. doi: 10.5712/rbmfc12(39)1430

27. Edwards ST, Helfrich CD, Grembowski D, Hulen E, Clinton WL, Wood GB, et al. Task delegation and burnout trade-offs among primary care providers and nurses in veterans affairs patient aligned care teams (VA PACTs). J Am Board Fam Med. 2018;31(1):83-93. doi: 10.3122/ jabfm.2018.01.170083 
28. Leonelli LB, Andreoni S, Martins P, Kozasa EH, Salvo VL, Sopezki D, et al. Perceived stress among primary health care professionals in Brazil. Rev Bras Epidemiol. 2017;20(2):286-98. doi: 10.1590/1980-5497201700020009

29. Moreira IJB, Horta JA, Duro LN, Borges DT, Cristofari AB, Chaves J, et al. Perfil sociodemográfico, ocupacional e avaliação das condições de saúde mental dos trabalhadores da Estratégia Saúde da Família em um município do Rio Grande do Sul, RS. Rev Bras Med Fam Comunidade. 2016;11(38):1-12. doi: 10.5712/rbmfc11(38)967

30. Teixeira PR, Lourenção LG, Gazetta CE, Gonsalez EG, Rotta DS, Pinto MH, et al. Engagement no Trabalho em Residentes Médicos de Pediatria. Rev Bras Educ Med. 2017;41(1):126-33. doi: 10.1590/1981-52712015v41n1rb20160039

31. Gonsalez EG, Lourenção LG, Teixeira PR, Rotta DS, Gazetta CE, Beretta D, et al. Work engagement in employees at professional improvement programs in health. Cad Bras Ter Ocup. 2017;25(3):509-17. doi: 10.4322/2526-8910.ctoAO0987

32. Lourenção LG. Work engagement among participants of residency and professional development programs in nursing. Rev Bras Enferm [Internet]. 2018;71(Supl 4):1487-92. doi: 10.1590/0034-7167-2017-0278

33. White M, Wells JGS, Butterworth T. The impact of a large-scale quality improvement programme on work engagement: preliminary results from a national cross-sectional-survey of the 'Productive Ward'. Int J Nurs Stud. 2014;51(12):1634-43. doi: 10.1016/j.ijnurstu.2014.05.002

34. Aboshaiqah AE, Hamadi HY, Salem OA, Zakari NM. The work engagement of nurses in multiple hospital sectors in Saudi Arabia: a comparative study. J Nurs Manag. 2016;24(4):540-8. doi: 10.1111/jonm.12356

35. Mukkavilli M, Kulkarni S, Doshi D, Reddy S, Reddy P, Reddy S. Assessment of work engagement among dentists in Hyderabad. Work. 2017;58(3):333-40. doi: 10.3233/WOR-172630

36. Setti I, Argentero P. Organizational features of workplace and job engagement among Swiss healthcare workers. Nurs Health Sci. 2011;13(4):425-32. doi: 10.1111/j.1442-2018.2011.00636.x

37. Bhuvanaiah T, Raya RP. Predicting employee work engagement levels, determinants and performance outcome: empirical validation in the context of an information technology organization. Glob Bus Rev. 2016;17(4):934-51. doi: 10.1177/0972150916645696 